\title{
Evaluation of Combining Abilities of New Sunflower Inbred Lines
}

\author{
Mihajlo Ćirić • Siniša Jocić • Sandra Cvejić • Petar Čanak • \\ Milan Jocković • Radovan Marinković • Milan Mirosavljević
}

\author{
received: 5 February 2013, accepted: 29 April 2013 \\ published online: 11 June 2013 \\ (c) 2013 IFVC \\ doi: $10.5937 /$ ratpov $50-3320$
}

\begin{abstract}
Summary: Days to flowering, plant height and head diameter are significant parameters which are directly or indirectly correlated with yield, main trait of sunflower. Eight CMS lines, three testers and their twenty four hybrids were examined by line $\mathrm{x}$ tester method. Significant differences were found between lines, testers and hybrids. Results showed that lines PD-3 and PD-25 had good combining abilities for the trait of days to flowering ( 58 days and 65 days, respectively). In the expression of plant height best combiners were PD-2 $(107.5 \mathrm{~cm})$ and PD-3 $(108.7 \mathrm{~cm})$. For head diameter lines PD-52 $(24.5 \mathrm{~cm})$ and MA- $57(23.2 \mathrm{~cm})$ were marked as good combiners. Variance of SCA was greater than variance of GCA for all the traits. CMS lines had the greatest part in the expression of the analyzed traits. Non-additive type of gene effect was reported for all examined traits, which implies that they could be improved through heterosis breeding.

Key words: CMS, combining ability, crop yield, days to flowering, head diameter, hybrids, inbreds, plant height, sunflower
\end{abstract}

\section{Introduction}

Sunflower is an agricultural crop which is grown on over 23 million hectares in the world (FAO 2012). In current oil seed production, sunflower has a prominent role as one of the most important oil crop species. Stability, higher yield, good self-fertility, uniformity at maturity and easier input of resistance to plant disease and pests are all advantages of hybrids (Sujatha et al. 2002, Kaya \& Atakisi 2004, Kaya 2005, Jocić et al. 2012). Phenomenon of heterosis is widely used in sunflower breeding and commercial production. It manifests as the vigor of F1 generation (or F1 hybrids) and is expressed through rapid growth, higher, bigger and generally robust plants, and greater yield values. Sunflower F1 hybrids are produced by crossing cytoplasmic male sterile lines with lines for restoration fertility or RF lines. For expression of hybrid power (heterosis) it is necessary to find the right combination of

M. Ćirić* • S. Jocić • S. Cvejić • P. Čanak • M. Jocković • R. Marinković • M. Mirosavljević

Institute of Field and Vegetable Crops, Maksima Gorkog 30, 21000

Novi Sad, Serbia

e-mail: mihajlo.ciric@ifvcns.ns.ac.rs parents since this phenomenon does not always occur (Hladni et al. 2007). Value of lines for hybrids is found through their crossings and it is presented by parameter called combining ability. Sprague and Tatum (1942) specify that there are two types of combining ability, general combining ability (GCA) which represents the average value of parent in his crossings, and specific combining ability (SCA) which represents value of parent in crossing with specific line or a parent.

There are several methods for evaluating combining abilities of inbred lines. Beside diallel method, line $\mathrm{x}$ tester analysis is the most commonly used technique for evaluation of GCA and SCA of sunflower inbred lines and hybrids (Ahmad et al. 2012). It enables us to assess great number of genotypes and to determine their combining abilities. Line $x$ tester analysis is a version of top cross method which uses several testers and assesses lines by their progeny. Tester is a line or a variety with broad genetic base known for its good combining ability (Jocić et al. 2012).

\footnotetext{
Acknowledgements:

This study was supported by Ministry of Education, Science and Technological Development of the Republic of Serbia, project TR 31025.
} 
Yield represents a complex trait affected by many parameters (Marinković 1989). Morphological characteristics like plant height and head diameter are some of the traits which affect the sunflower yield (Gvozdenović et al. 2005). Also, days to flowering is an important parameter for sunflower especially for development hybrids for different agro-climatic zones.

The aim of this study was to obtain the information about GCA of inbred lines, SCA of F1 hybrids, the gene effect components of genetic variance and average contribution of RF lines, testers and their interaction in the expression of days to flowering, plant height and head diameter.

\section{Materials and Methods}

Eight new CMS inbred lines were examined for their combining abilities. RF inbred lines were used as testers. The plot also included twenty four of their hybrid combinations. Inbred lines were PD-2, PD-3, PD-12, PD-25, PD-33, PD-39, PD-52, MA-57 and testers were MG-1, MG-2,
MG-3. Hybrid combinations were created by crossing CMS inbred lines with RF testers during the summer of 2009. In 2010 all genotypes were examined in randomized complete block design in three replications.

The trial was located at the Experimental field of the Institute of Field and Vegetable Crops in Novi Sad, Serbia. Seeds of lines and hybrids were sown by mechanical seeder in the beginning of April 2010. The row-to-row spacing was $70 \mathrm{~cm}$ and plantto-plant spacing was $25 \mathrm{~cm}$. Sample for analysis included 30 plants (10 for each replication). Measurements of plant height and head diameter were carried out during the phase of physiological maturity.

Results of line $\mathrm{x}$ tester analysis (Singh \& Choudhary 1976) showed information about significant differences between sources of variance, GCA of lines and SCA of hybrid combinations. Also, information about components of variance and average contribution of lines, testers and their interaction in earliness and plant height were obtained using Microsoft Excel.

Table 1. Analysis of variance for lines $\mathrm{x}$ testers including parents presented through mean square values for days to flowering, plant height and head diameter in sunflower genotypes

Tabela 1. Analiza varijanse za liniju x tester sa roditeljima predstavljena preko srednjih vrednosti za broj dana do cvetanja, visinu biljke i prečnik glave kod genotipova suncokreta

\begin{tabular}{|c|c|c|c|c|}
\hline & $\begin{array}{l}\text { Degree of freedom } \\
\text { Stepeni slobode }\end{array}$ & $\begin{array}{l}\text { Days to flowering } \\
\text { Dani do cretanja }\end{array}$ & $\begin{array}{l}\text { Plant } \\
\text { height } \\
\text { Visina } \\
\text { biljke }\end{array}$ & $\begin{array}{l}\text { Head diameter } \\
\text { Prečnik } \\
\text { glave }\end{array}$ \\
\hline Replications & & & & \\
\hline Ponavljanja & 2 & 3.81 & 70.59 & 0.19 \\
\hline $\begin{array}{l}\text { Genotypes } \\
\text { Genotipovi }\end{array}$ & 34 & $54.62^{* *}$ & $4276.71^{* *}$ & $28.94^{* *}$ \\
\hline $\begin{array}{l}\text { Parents } \\
\text { Roditelji }\end{array}$ & 10 & $146.59^{* *}$ & $2499.32^{* *}$ & $37.63^{* *}$ \\
\hline $\begin{array}{l}\text { Parents vs crossings } \\
\text { Roditelji kroz ukrštanja }\end{array}$ & 1 & 3.33 & $103499.10^{* *}$ & $361.90^{* *}$ \\
\hline $\begin{array}{l}\text { Crossings } \\
\text { Ukrštanja }\end{array}$ & 23 & $16.86^{* *}$ & $735.48^{* *}$ & $10.68^{* *}$ \\
\hline $\begin{array}{l}\text { Lines } \\
\text { Linije }\end{array}$ & 7 & $44.38^{* *}$ & $2154.13^{* *}$ & $27.33^{* *}$ \\
\hline $\begin{array}{l}\text { Testers } \\
\text { Testeri }\end{array}$ & 2 & 5.06 & 19.48 & $14.58^{* *}$ \\
\hline $\begin{array}{l}\text { Line } x \text { testers } \\
\text { Linija } x \text { tester }\end{array}$ & 14 & $4.79^{*}$ & $128.44^{* *}$ & 1.80 \\
\hline $\begin{array}{l}\text { Error } \\
\text { Greška }\end{array}$ & 68 & 2.09 & 45.31 & 1.74 \\
\hline $\begin{array}{l}\text { Total } \\
\text { Ukupno }\end{array}$ & 104 & & & \\
\hline
\end{tabular}

${ }^{* *}$ significant at level 1\%, *significant at level 5\%

${ }^{* *}$ nivo značajnosti $1 \%,{ }^{*}$ nivo značajnost $5 \%$ 


\section{Results and Discussion}

Days to flowering

Analysis of variance shows that mean squares due to lines, hybrids and line $\mathrm{x}$ tester interaction were significant for days to first flowering (Table
1). Khan et al. (2009) report that late flowering sunflower genotypes have shorter filling period and therefore smaller seed weight. For thischaracteristic, negative values of GCA and SCA are preferred. Days to flowering is an important quantitative trait especially for developing genotypes adapted to various agro-climatic conditions (Putt 1940).

Table 2. Average number of days to flowering, average plant height and head diameter for parents and crossings in sunflower genotypes

Tabela 2. Prosečan broj dana do cvetanja. prosečna visina biljke i prosečan prečnik glave kod roditelja i ukrštanja kod genotipova suncokreta

\begin{tabular}{|c|c|c|c|}
\hline $\begin{array}{l}\text { Genotype } \\
\text { Genotip }\end{array}$ & $\begin{array}{l}\text { Days to flowering } \\
\text { Dani do cvetanja }\end{array}$ & $\begin{array}{l}\text { Plant height }(\mathrm{cm}) \\
\text { Visina biljke }(\mathrm{cm})\end{array}$ & $\begin{array}{c}\text { Head diameter }(\mathrm{cm}) \\
\text { Prečnik glave }(\mathrm{cm})\end{array}$ \\
\hline PD-2 x MG-1 & 66 & 196.0 & 23.1 \\
\hline PD-2 $\times$ MG-2 & 66 & 190.2 & 20.9 \\
\hline PD-2 $\times$ MG-3 & 67 & 198.0 & 22.9 \\
\hline PD-3 x MG-1 & 64 & 192.0 & 21.3 \\
\hline PD-3 x MG-2 & 65 & 200.3 & 20.0 \\
\hline PD-3 x MG-3 & 63 & 182.7 & 21.3 \\
\hline PD-12 x MG-1 & 66 & 198.5 & 20.8 \\
\hline PD-12 x MG-2 & 67 & 191.8 & 19.4 \\
\hline PD-12 x MG-3 & 67 & 196.5 & 21.2 \\
\hline PD-25 x MG-1 & 63 & 193.7 & 21.1 \\
\hline PD-25 x MG-2 & 63 & 196.7 & 21.8 \\
\hline PD-25 x MG-3 & 66 & 195.2 & 22.2 \\
\hline PD-33 x MG-1 & 64 & 187.2 & 20.0 \\
\hline PD-33 x MG-2 & 67 & 202.5 & 18.7 \\
\hline PD-33 x MG-3 & 65 & 186.8 & 19.3 \\
\hline PD-39 x MG-1 & 67 & 225.8 & 21.1 \\
\hline PD-39 x MG-2 & 68 & 218.5 & 19.0 \\
\hline PD-39 x MG-3 & 69 & 224.7 & 22.5 \\
\hline PD-52 x MG-1 & 67 & 200.0 & 22.6 \\
\hline PD-52 x MG-2 & 67 & 196.3 & 23.0 \\
\hline PD-52 x MG-3 & 68 & 204.5 & 25.3 \\
\hline MA- 57 x MG-1 & 72 & 239.0 & 25.0 \\
\hline MA- $57 \times$ MG-2 & 68 & 221.5 & 24.4 \\
\hline MA- $57 \times$ MG-3 & 72 & 235.3 & 24.6 \\
\hline PD-2 & 62 & 107.5 & 17.7 \\
\hline PD-3 & 58 & 108.7 & 16.5 \\
\hline PD-12 & 71 & 115.0 & 14.7 \\
\hline PD-25 & 65 & 131.5 & 17.2 \\
\hline PD-33 & 64 & 127.2 & 18.8 \\
\hline PD-39 & 69 & 138.0 & 14.4 \\
\hline PD-52 & 51 & 108.5 & 24.5 \\
\hline MA-57 & 76 & 198.2 & 23.2 \\
\hline MG-1 & 71 & 128.0 & 14.6 \\
\hline MG-2 & 69 & 160.8 & 13.9 \\
\hline MG-3 & 71 & 166.5 & 19.5 \\
\hline
\end{tabular}


The results of evaluated lines showed that there were significant differences among the studied genotypes. Values of GCA and SCA effects were compared using LSD test (Table 3.).The shortest vegetation period until flowering was recorded at line PD-52 (51 days) and the longest at line MA57 (76 days). The testers showed low distinction for the days to flowering, MG-2 had 69 days and the other two testers MG-1 and MG-3 both had 71 days to flowering. Among F1 hybrids the three combinations, PD-25 x MG-1, PD-25 x MG-2 and PD-3 $\times$ MG-3, had the lowest number of days to flowering of 63 days. The highest number of days to flowering of 72 days was found in two combinations, MA-57 x MG-1 and MA-57 x MG-3 (Table 2).

Variance of SCA was greater than variance of GCA for days to flowering which indicates that higher amount of genetic variability was caused by SCA effect (Table 5). Results suggest that the trait was under greater influence of non-additive type of gene action. These results are contrary to Ortis et al. (2005), Škorić et al. (2000) and Marinković et al. (2000).

Among CMS inbred lines maximum negative GCA effect was found in line PD-25 (-2.78), whereas maximal positive effect was found in line MA-57 (4.00). One of the twenty four crossings showed significant negative SCA effect (Table 4). Testers did not show any significant effect for the expression of days to flowering (Table 3). If the aim is to obtain lines with fewer days to flowering then the right choice would be lines PD-3 and PD-25 and crosses MA-57 x MG-2. Average contribution of lines in the expression of days to flowering was $80.11 \%$, while line $\mathrm{x}$ tester interaction $(17.28 \%)$ and testers $(2.61 \%)$ had lesser part in manifestation of this trait (Table 6). The major role of lines in the expression of this trait is in disagreement with the results of Khan et al. (2009).

\section{Plant height}

Plant height belongs to the group of quantitative traits. In recent years a high level of interest is present for creation of semi-dwarf sunflower hybrids and their application in agricultural practice. In some cases of crossing reduced plant height appears, but in other cases it is not present, which implies a complex genetic control of this characteristic (Khan et al. 2009). In the case of plant height negative values of GCA and SCA are preferable (Khan et al. 2009, Gvozdenović et al. 2005).

Average plant height between lines varied from $107.5 \mathrm{~cm}$ at line PD-2 to $198.2 \mathrm{~cm}$ at line MA- 57 .
Among testers the plant height ranged between $128.0 \mathrm{~cm}$ at MG-1 to $166.5 \mathrm{~cm}$ at line MG-3. Plant height of F1 hybrids varied between 182.7 $\mathrm{cm}$ at combination PD-3 x MG-3 to $239.0 \mathrm{~cm}$ at hybrid combination MA-57 x MG-1 (Table 2.).

Variance of SCA was greater than variance of GCA for the trait of plant height which indicates that higher amount of genetic variability was caused by SCA effect which implies that nonadditive gene effect is responsible for expression of this characteristic. For improvement of this trait methods of heterosis breeding should be used. These conclusions are in agreement with the results of Ahmad et al. (2012) and in disagreement with the results of Khan et al. (2009), Ortis et al. (2005); Joksimović et al. (2000); Hladni et al. (2000).

Analysis of variance indicates that mean squares due to parental lines, parents through crossings, crossings and line $\mathrm{x}$ tester interaction were significant for plant height (Table 1). Since lower plant height genotypes of sunflower are desirable (Škorić 1980), interesting and potentially valuable parental lines were: $\mathrm{PD}-3$ (-12.40), PD-12 (-10.68) and PD-33 (-10.79). Undesirable parent with maximal positive effect for plant height was MA-57 (28.97). One of the twenty-four crossings showed significant positive SCA effect (Table 4). Lines had the highest effect on plant height $(89.14 \%)$, followed by line $\mathrm{x}$ tester interaction $(10.63 \%)$ and testers $(0.23 \%$, as shown in Table 6. These results concur with the results of Ortis et al. (2005).

\section{Head diameter}

Head diameter is a morpho-physiological trait with indirect effect on yield. This characteristic is under great influence of environmental factors. Therefore it has low level heritability which is a limiting factor in breeding. In sunflower breeding program the objective is to create hybrids with large head diameter that could carry large number of fertile flowers. In sunflower breeding characteristics and morphology of sunflower head are of great importance (Mijić et al. 2005). Head diameter is in direct correlation with number of florets per head and number of seeds per head therefore it affects on the yield per plant (Hladni et al. 2010).

Analysis of variance for head diameter shows that mean squares due to parents, crossings, parents through crossing, lines and hybrids were significant (Table 1). For this morphophysiological trait genotypes with large head diameter are sought. Favourable lines for this 
characteristic would be lines PD-52 (2.92) and MA-57 (1.93). Lines with less desirable head diameter but with significant GCA effect are PD-12 (-1.25) and PD-33 (-2.38) (Table 3.). However, hybrid combinations had no significant SCA effects for head diameter (Table 4). Past studies over inheritance of head diameter have showed different results. Greater variance of GCA than the variance of SCA shows that this trait is influenced by additive gene effect which complies with the conclusions of Škorić \& Marinković (1990) and disagrees with the findings of Ahmad et al. (2012) and Joksimović et al. (2000).
The smallest average head diameter among lines was found in line PD-39 $(14.4 \mathrm{~cm})$ and the largest head diameter was found in line MA-52 $(24.5 \mathrm{~cm})$. Among testers the smallest diameter of sunflower head was measured at tester MG-2 $(13.9 \mathrm{~cm})$ and the largest head diameter at tester MG-3 $(19.5 \mathrm{~cm})$. F1 hybrids head diameter ranged from $18.7 \mathrm{~cm}$ at combination PD-33 x MG-2 to $25.3 \mathrm{~cm}$ at combination PD-52 x MG-3 (Table 2). Lines had the greatest part in the expression of head diameter $(77.86 \%)$, while the parts of line $\mathrm{x}$ tester interaction (11.87\%) and testers (10.28\%) were approximately equal (Table 6).

Table 3. GCA effects of lines and testers for days to flowering, plant height and head diameter Tabela 3. Efekti OKS za linije i testere za broj dana do cvetanja, visinu biljke i prečnik glave

\begin{tabular}{|c|c|c|c|c|}
\hline $\begin{array}{l}\text { Lines / GCA } \\
\text { Linije/ OKS }\end{array}$ & & $\begin{array}{l}\text { Days to flowering } \\
\text { Dani do cvetanja }\end{array}$ & $\begin{array}{l}\text { Plant height } \\
\text { Visina biljke }\end{array}$ & $\begin{array}{l}\text { Head diameter } \\
\text { Prečnik } \\
\text { glave }\end{array}$ \\
\hline PD-2 & & -0.22 & $-8.35^{* *}$ & 0.54 \\
\hline PD-3 & & $-2.44^{* *}$ & $-11.40^{* *}$ & -0.87 \\
\hline PD-12 & & -0.11 & $-7.46^{*}$ & $-1.25^{*}$ \\
\hline PD-25 & & $-2.78^{* *}$ & $-7.90^{*}$ & -0.03 \\
\hline PD-33 & & -1.00 & $-10.90^{* *}$ & $-2.38^{* *}$ \\
\hline PD-39 & & $1.78^{* *}$ & $19.93^{* *}$ & -0.86 \\
\hline PD-52 & & 0.78 & -2.79 & $1.93^{* *}$ \\
\hline MA-57 & & $4.00^{* *}$ & $28.88^{* *}$ & $2.92^{* *}$ \\
\hline \multicolumn{5}{|l|}{$\begin{array}{l}\text { Testers } \\
\text { Testeri }\end{array}$} \\
\hline MG-1 & & -0.44 & 0.95 & 0.15 \\
\hline MG-2 & & -0.03 & -0.84 & $-0.84^{*}$ \\
\hline MG-3 & & 0.47 & -0.11 & 0.69 \\
\hline \multicolumn{5}{|l|}{ S.E.(GCA for lines) } \\
\hline $\begin{array}{l}\text { S.E.(GCA for testers) } \\
\text { S.E. (OKS za testere) } \\
\text { S.E.(gi-gj lines) }\end{array}$ & & 0.30 & 1.37 & 0.27 \\
\hline \multicolumn{5}{|l|}{ S.E.(gi-gj testers) } \\
\hline \multicolumn{5}{|l|}{ LSD lines } \\
\hline NZR linija & 0,05 & 1,36 & 6,35 & 1,24 \\
\hline LSD testers & 0,01 & 1,81 & 8,44 & 1,66 \\
\hline \multirow[t]{2}{*}{ NZR testera } & 0,05 & 0,84 & 3,89 & 0,76 \\
\hline & 0,01 & 1,11 & 5,17 & 1,01 \\
\hline
\end{tabular}

${ }^{* *}$ significant at $1 \%$ level, ${ }^{*}$ significant at $5 \%$ level

${ }^{* *}$ nivo značajnosti $1 \%,{ }^{*}$ nivo značajnosti $5 \%$ 
Table 4. SCA effects for hybrids for days to flowering, plant height and head diameter Tabela 4. Efekti PKS za hibride za broj dana do cvetanja, visinu biljke i prečnik glave

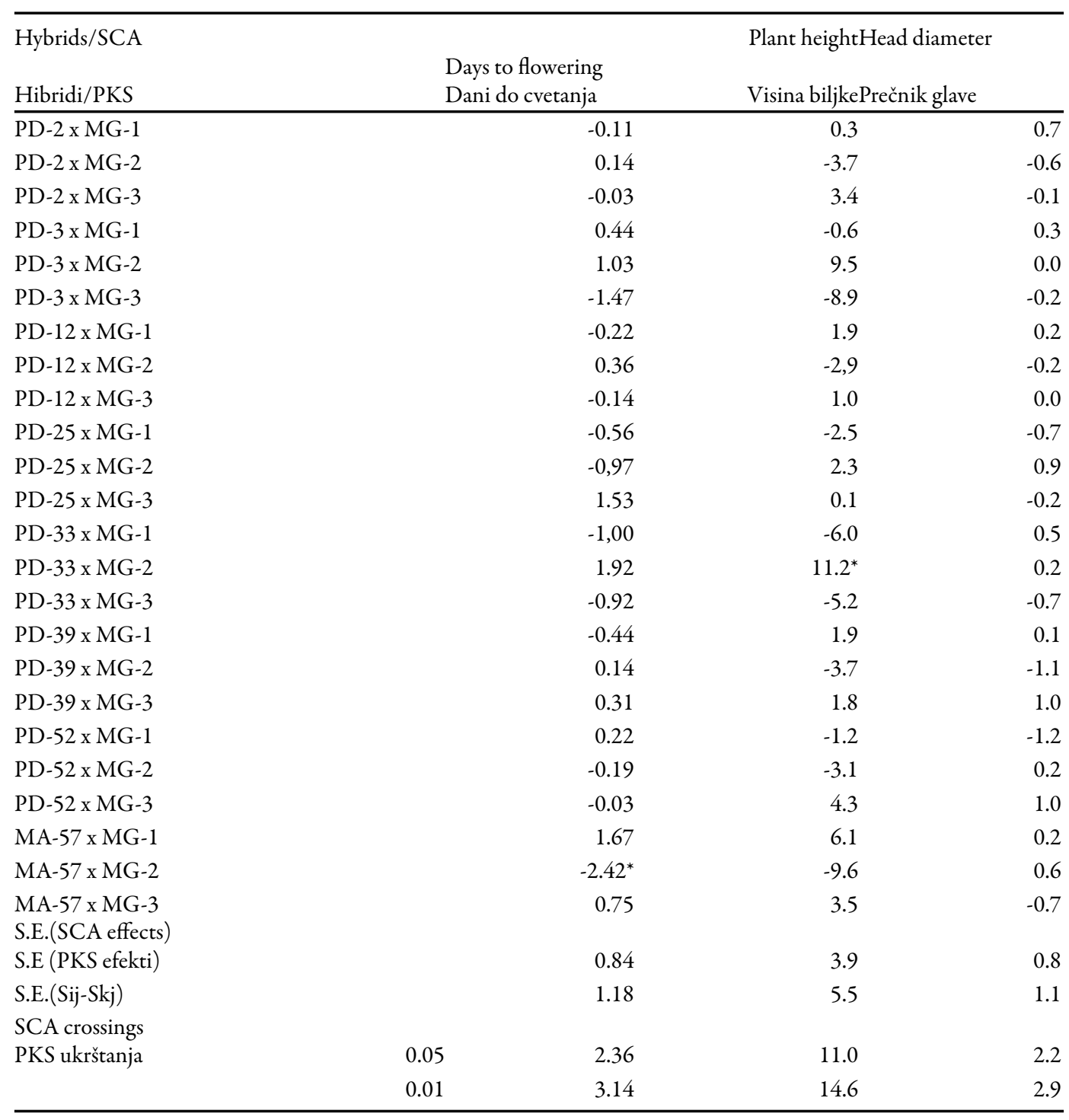

${ }^{* *}$ significant at $1 \%$ level, * significant at $5 \%$ level

${ }^{* *}$ nivo značajnosti $1 \%,{ }^{*}$ nivo značajnosti $5 \%$

Table 5. Estimates of genetic components for days to flowering, plant height and head diameter Tabela 5. Procena genetičkih komponenti za broj dana do cvetanja, visinu biljke i prečnik glave

\begin{tabular}{lccc}
\hline Gene action & $\begin{array}{c}\text { Days to flowering } \\
\text { Dani do cvetanja }\end{array}$ & Plant height & Head diameter \\
Efekat gena & 0.90 & 27.71 & 0.02 \\
\hline $\begin{array}{l}\text { Variance due to non additive type of gene action } \\
\text { Varijansa aditivnog efekta gena }\end{array}$ & & 26.52 & Prečnik glave \\
$\begin{array}{l}\text { Variance due to additive type of gene action } \\
\text { Varijansa dominantnog efekta gena }\end{array}$ & 0.53 & 0.39 \\
\hline
\end{tabular}


Table 6. Average contribution (\%) for the expression of days to flowering, plant height and head diameter Tabela 6. Prosečan doprinos (\%) u ispoljavanju broja dana do cvetanja, visine biljke i prečnika glave

\begin{tabular}{lccc}
\hline $\begin{array}{l}\text { Trait } \\
\text { Osobina }\end{array}$ & $\begin{array}{c}\text { Days to flowering } \\
\text { Dani do cvetanja }\end{array}$ & $\begin{array}{c}\text { Plant height } \\
\text { Visina biljke }\end{array}$ & $\begin{array}{c}\text { Head diameter } \\
\text { Prečnik glave }\end{array}$ \\
\hline $\begin{array}{l}\text { Line } \\
\text { Linija } \\
\text { Testers } \\
\text { Testeri }\end{array}$ & 80.11 & 89.14 & 77.9 \\
Lx T & 2.61 & 0.23 & 11.9 \\
\hline
\end{tabular}

\section{Conclusions}

Results of the analysis show that there were significant differences between genotypes for the traits of days to flowering, plant height and head diameter. Variance of SCA was greater than variance of GCA for all the investigated traits. For the trait days to flowering, lines PD-3 and PD-25 were marked as good combiners. In the expression of plant height best combiners were PD-2 and PD-3. Good combiners for characteristic head diameter were lines PD-52 and MA-57. Higher amount of genetic variability was caused by SCA effect which reports non-additive type of gene action for all examined characteristics. The CMS lines had the greatest part in the expression of all the studied characteristics. These traits could be improved through heterosis breeding and used in sunflower seed production.

\section{References}

Ahmad, W. A., Ahmed, M. S., \& Tahir, H. N. (2012). Combining ability analysis for achene yield and related traits in sunflower (Helianthus annuus L.). C. J. Agri. Res. 72(1), 21-26.

FAOSTAT-FAO (2012). Area harvested. Food and Agriculture Organization of the United Nations. Available at http://faostat.fao.org/site/567/DesktopDefault.aspx?PageID=567\# ancor (cited: 19 January 2012)

Gvozdenović, S., Joksimović, J., \& Škorić, D. (2005). Gene effect and combining abilities for plant height and head diameter in sunflower. Genetika, 37 , 57-64.

Hladni, N., Škorić, D., \& Kraljević-Balalić, M. (2000). Kombinirajuće sposobnosti za komponente prinosa suncokreta. Selekcija i semenarstvo, 7, 141-147.

Hladni, N., Škorić, D., Kraljević-Balalić, M., Sakač, Z., \& Miklič, V. (2007). Heterosis for agronomically important traits in sunflower (Helianthus annuus L.). Helia, 30(1), 91-198.

Hladni, N. (2010). Geni i prinos suncokreta / Genes and sunflower yield. Zadužbina Andrejević/ Institut za ratarstvo i povrtarstvo Novi Sad.

Jocić, S., Cvejić, S., Ćirić, M., Hladni, N., Miladinović, D., Miklič, V., \& Radeka, I. (2012). Estimation of combining abilities in sunflower (Helianthus annuus L.). Proceedings of the $18^{\text {th }}$ International Sunflower Conference. Mar Del Plata \& Balcare, Argentina, 657662.

Joksimović, J., Atlagić, J., \& Škorić, D. (2000). Efekat gena i kombinacione sposobnosti za prečnik glave kod nekih inbred linija suncokreta. Selekcija $i$ semenarstvo, 7, 45-49.

Kaya, Y., \& Atakisi, I. (2004). Combining ability analysis of some yield characters of sunflower (Helianthus annuus L.). Helia, 27, 75-84. 
Kaya, Y. (2005). Determining Combining Ability in Sunflower (Helianthus annuus L.). Turk. J. Agric. 29, 243-250.

Khan, S. A., Ahmad, H., Khan, A., Saeed, M., Khan, S. M., \& Ahmad, B. (2009). Using line $\mathrm{x}$ tester analysis for earliness and plant height traits in sunflower (Helianthus annuus L.). Recent Res. Sci. Technol. 1, 202-206.

Marinković, R. (1989). Nasledivanje kvalitativnih i kvantitativnih svojstava. Suncokret (monografija), Nolit, Beograd.

Marinković, R., \& Škorić, D. (1990). Nasleđivanje prečnika glave i broja cvetova po glavi u ukrštanjima raznih inbred linija suncokreta (Helianthus annuus L.). Uljarstvo, 27, 22-27.

Marinković, R., Škorić, D., Dozet, B., \& Jovanović, J. (2000). Effect of PET1 and ANN5 cytoplasms on some quantitative traits in sunflower lines and hybrids. Helia, 23, 73-86.

Mijić, A., Krizmanić, M., Liović, I., Bilandžić, M., Zdunić, Z., \& Kozumplik, V. (2005). Procjena kombinacijskih sposobnosti i genetskih učinaka za visinu bilike i promjer glave suncokreta. Poljoprivreda, 11, 18-23.

Ortis, L., Nestares, G., Frutos, E., \& Machado, N. (2005). Combining ability for agronomic traits in sunflower (Helianthus annuus L.). Helia, 28, 125-134.

Putt, E. D. (1940). Observation on morphological characters and morphological process in sunflower (Helianthus annuus L.). Sci. Agric. 21, 167-179.

Singh, R. K., \& Choudhary, B. D. (1976). Biometrical techniques in genetics and breeding. Int. Bioscience $\mathrm{Pu}-$ blishers. Hisar, India

Sprague, G. F., \& Tatum, L. A. (1942). General vs. specific combining ability in single crosses of corn. J. Am. Soc. Agron. 34, 923-932.

Sujatha, H. L., \& Chikkdevaiah, N. (2002). Genetic variability study in sunflower inbreds. Helia, 25, 93-100.

Škorić, D., Jocić, S., \& Molnar, I. (2000). General (GCA) and specific (SCA) combining abilities in sunflower. Zbornik naucnih radova Instituta za ratarstvo $i$ pourtarstvo, 6, 97-105.

Škorić, D. (1980). Desired model of hybrid and the newly developed NS-hybrids. Helia, 3, 19-24.

\title{
Ocena kombinacionih sposobnosti novih inbred linija suncokreta
}

\author{
Mihajlo Ćirić • Siniša Jocić • Sandra Cvejić • Petar Čanak • \\ Milan Jocković • Radovan Marinković • Milan Mirosavljević
}

Izvod: Broj dana do cvetanja biljke, visina biljke i prečnik glave su značajni parametri koji su direktno ili indirektno povezani sa prinosom, glavnim svojstvom suncokreta. Osam CMS linija, tri testera i njihovih dvadeset četiri hibrida ispitivano je metodom linija $x$ tester. Značajne razlike su nađene između linija, testera i F1 hibrida. Rezultati su pokazali da dobre kombinacione sposobnosti za svojstvo broj dana do cvetanja poseduju linije PD-3 (58 dana) i PD-25 (65 dana). U ispoljavanju visine biljke kao najbolji kombinatori su se pokazale linije PD-2 $(107,5 \mathrm{~cm})$ i PD-3 $(108,7 \mathrm{~cm})$. Za prečnik glave linije PD-52 (24,5 cm) i MA- $57(23,2 \mathrm{~cm})$ su označene kao dobri kombinatori. Najveći značaj u ispoljavanju navedenih svojstava imale su CMS linije. Varijansa uzrokovana PKS je bila veća od varijanse uzrokovane OKS za sva svojstva. Neaditivan efekat gena je zapažen u ispoljavanju svih ispitivanih osobina, što pokazuje da one mogu biti poboljšane metodom oplemenjivanja na heterozis.

Ključne reči: CMS, dani do cvetanja, hibridi, inbred linije, kombinaciona sposobnost, prečnik glave, prinos useva, suncokret, visina biljke 